\title{
Sugar composition of floral nectar in sour cherry cultivars*
}

\author{
Orosz-Kovács Zs. ${ }^{1}$, Szabó L. Gy. ${ }^{1}$, Bubán T. ${ }^{2}$, Farkas Á. ${ }^{1}$ \\ and Bukovics P. ${ }^{1}$
}

${ }^{I}$ University of Pécs, Department of Botany, H-7624 Pécs, Ifjúság u. 6.

${ }^{2}$ Research and Extension Centre for Fruitgrowing, $H-4244$ Ujfehértó, P.O. Box. 38

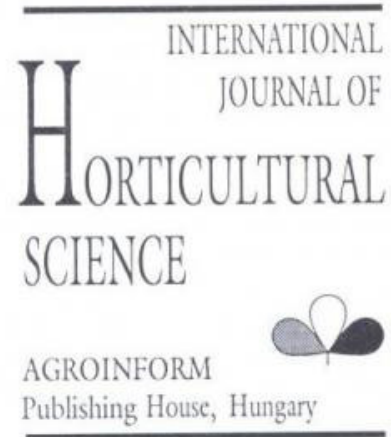

Key words: sour cherry, floral nectar sugar components, floral biology

Summary: The composition of floral nectar in sour cherry cultivars studied in 1997 at Újfehértó was in agreement with our previous data, the three most frequent sugar components being glucose, fructose and sucrose. Nectar secreted at night is generally more diluted than nectar produced during the day. None of the nectar samples produced at night reached the threshold value $(100 \mathrm{mg} / \mathrm{ml})$ of bee visitation. In the majority of cultivars the difference in concentration between night and day nectar is not too high, but in two cultivars, 'Korai pipacs' and 'Ujfehértói fürtös' the difference is quite significant. Most sucrose was found in the nectar of cvs. 'Érdi jubileum' and 'Újfehértói fürtös', but a high amount of sucrose was measured also in the flowers of 'Korai pipacs' and 'Meteor USA'. Nectar concentration varies from opening of the flower to petal fall to a smaller or greater degree, depending on the given cultivar. From the 9 sour cherry cultivars studied 'Ujjehértói fürtös' and 'Pándy 48' had the most attractive nectar for bees. There was no correlation between nectar composition and free fertilisation. On the basis of nectar composition the majority of the sour cherry cultivars studied can be classified into the sucrose-rich category; only one cultivar, 'Érdi jubileum' had a sucrose-dominant secretory product. The composition of nectar in the studied sour cherry cultivars is preferred by bees.

\section{Introduction}

The floral nectar of our temperate zone fruit trees is dominantly the aqueous solution of sugars. Nectar, however, contains also organic acids, vitamin C, amino acids, phosphatases, glycosides, mineral salts and aromatic substances according to Maurizio (1960), Kartashova (1965), and Baker \& Baker (1983).

Percival (1961), studying the sugar composition of nectar in 889 angiospermous species, stated that the three most frequent and abundant sugar components are glucose, fructose and sucrose. On the basis of these three sugars she described 10 types of nectar, which were classified into 3 groups: 1. sucrose-dominant, 2. sucrose, glucose and fructose is balanced, 3. glucose- and fructose-dominant. The author described all three main sugar components in Rosaceac taxa.

According to Baker \& Baker (1990) the sucrose/ glucose+fructose quotient and the structure of the flower or the inflorescence may refer to the pollinator. The above authors distinguished four nectar types: 1. hexose-dominant, where $\mathrm{S} / \mathrm{G}+\mathrm{F}<0,1 ; 2$. hexose-rich, which can be characterised by $\mathrm{S} / \mathrm{G}+\mathrm{F}=0,1-0,49$. These nectars are preferred by small bees. The third type is the sucrose-rich, for which $\mathrm{S} / \mathrm{G}+\mathrm{F}=0,5-0,99$ is characteristic. The fourth type, however can be characterised by $\mathrm{S} / \mathrm{G}+\mathrm{F}>1$. Large bees prefer nectar with sucrose dominance, i.e. the latter two types.

Örösi (1968) claims that bees do not perceive nectar as sweet, if sucrose in it does not reach $4 \%$, or the mixture of glucose and fructose is more diluted than $8-9 \%$.

Among Rosaceae taxa fruit cultivars have been examined by a number of researchers. Benedek \& Nyéki (1997) studied the nectar composition of several fruit species and stated that bee visitation was in strong correlation with sugar concentration of nectar.

Campbell et al. (1990) described the nectar of crab apples as mainly sucrose-dominant on the basis of their investigations in 1988.

Davary-Nejad et al. (1993) found that nectar composition varied in different apple cultivars. In their samples $50 \%$ of total sugar content was sucrose, whereas the rest was divided between fructose and glucose.

The nectar of the ten apple cultivars studied by OroszKovács et al. (1997) contained glucose, fructose and sucrose. The cultivars can basically be classified into two groups on the basis of the quotient $\mathrm{S} / \mathrm{G}+\mathrm{F}$ : the majority of them belonged to the sucrose-rich group, while one cultivar had a sucrose-dominant nectar. 
Szabo et al. (2000) studied the composition of floral nectar in some cultivars belonging to Maloideae taxa: Malus domestica L., Pyrus communis L. and Cydonia oblonga Mill. They stated that the presence of glucose and fructose is a general characteristic, but sucrose is also present in some cultivars. Honey bees play a role in the pollination of mainly self-sterile apple, pear and quince cultivars, if nectar contains sucrose, as well, and its concentration is above the threshold of bee visitation. Apple nectar can be characterised by such nectar, preferred by bees. The nectar of the studied pear cultivars contained no sucrose at all, and the concentration of glucose and fructose was also low. Their pollination is often carried out by flies. In some quince cultivars nectar consisted only of glucose and fructose, others contained sucrose, too. In some cultivars the refraction of the secretory product did not even reach the threshold $(10 \%)$ of bee visitation.

Among Prunoidea taxa the nectar composition of some plum cultivars was already described in our previous works (Majer-Bordács et al., 1989). It was stated that the secretory product of self-fertile plum cultivars is rich in glucose and poor in sucrose, whereas that of self-sterile cultivars was richer in sucrose.

It was also described in one of our previous papers (Majer-Bordács et al., 1993) that the nectar of apricot cultivars is diluted and can be characterised by the absence or small amount of sucrose. The secretory product of selffertile cultivars contained only hexoses, while the autosterile ones could be characterised by a more concentrated sugar solution, where however, sucrose was also absent or present only in small amounts. For the partially self-fertile cultivars the simultaneous presence of the three sugar components was characteristic.

As a summary of our studies on Prunoideae fruit cultivars (Botz et al., 2000) it can be stated that it is a general characteristic of stone fruit cultivars blooming in early spring that their flowers produce a sucrose-poor nectar or it may lack sucrose altogether. It may be in connection with the dominance of wind-pollination and self-fertility. Earlyblooming almond cultivars produce a diluted nectar with two components, glucose and fructose. Only the floral secretory product of a single cultivar, 'Tétényi bötermö', contained a little amount of sucrose. The nectar of peach cultivars, also blooming early, but slightly later than almonds, contains already a little sucrose. The nectar of later blooming sour cherry cultivars contains more than $30 \%$ sucrose besides glucose and fructose. These fruit cultivars are the most visited by bees among stone fruits. When matching cultivars, it is advisable to pay attention to the composition and concentration of floral nectar, because pollination may not occur because of the sugar preference of bees.

\section{Material and methods}

Samples were collected in 1997 in the cultivar collection of the Research and Extension Centre for Fruitgrowing,
Újfehértó. Comparing samples from the same year and same place is more likely to show real differences between cultivars. Nectar was drained from isolated flowers using a microcapillary, and $10 \mu \mathrm{l}$ was measured into small vials. Until analysis they were kept dried in an exiccator.

Nectar samples were taken twice a day from the flowers. Morning samples were collected at 6-7 o'clock from flowers isolated at 18-19 o'clock the previous evening, i.e. after 12 hours. Evening samples were taken at 18-19 o'clock, after a 24-hour isolation. Thus the morning samples contained mainly the nectar produced at night, whereas the evening samples contained the secretory product of both day and night.

Sugar components of nectar were identified by thin layer chromatography, quantitative determination was carried out by densitometry (CAMAG TLC Scanner II., at $510 \mathrm{~nm}$ wavelength). A known amount of the secretory product was applied to a $20 \times 20 \mathrm{~cm}$ plate with silica gel sorbent. Samples were developed twice without saturation using ethyl-acetate: ethanol : $60 \%$ acetic acid : water saturated with boric acid $(50: 20: 10: 10)$. After drying at room temperature, plates were treated with thymol reagent $(0.5 \mathrm{~g}$ thymol in $95.0 \mathrm{ml}$ ethanol; $5.0 \mathrm{ml}$ cc. sulphuric acid added). Finally densitometric evaluation was carried out.

\section{Results and conclusions}

It is known about the nectar of sour cherry cultivars that the three most frequent sugar components are glucose, fructose and sucrose (Orosz-Kovács, 1991, Botzet al., 2000). The nectar composition of sour cherry cultivars studied in 1997 was in agreement with our previous data.

Sour cherry cultivars with white corolla produce a significant amount of nectar also at night (Simidchiev, 1971, Orosz-Kovács, 1991). They attract also night insects, for which reason the composition of nectar produced at night was studied, as well.

Nectar produced at night in sour cherry cultivars is generally more diluted than nectar secreted during the day. The floral secretory product of sour cherry contains the sweeter sucrose in more than $30 \%$ besides glucose and fructose. Because of this, these cultivars possess the nectar composition preferred by bees to the greatest extent among stone fruits. Insect visitation of flowers varies, however, since flowers with higher sugar concentration may have a diverting effect from flowers having less sweet nectar.

In morning samples, which basically contained nectar produced at night, all three sugar components can be found, just like in nectar secreted during the day, but the concentration of the latter may be even twice as high as that of the night nectar, as e.g. in cv. 'Korai pipacs'. None of the morning samples reached the threshold $(100 \mathrm{mg} / \mathrm{ml})$ of bee visitation. This may explain the fact that bees were not present in the orchard before $8-9$ o'clock. At the majority of the cultivars the difference in concentration between night and day nectar was not great, but in two cultivars, 'Korai 
pipacs' and 'Ujfehértói fürtös', the difference was more than $25-30 \%$. Most sucrose could be detected in the nectar of 'Érdi jubileum' and 'Ujjechértói fürtös', but it was present in a significant amount also in the flowers of 'Korai pipacs' and 'Meteor USA' (Fig. 1-3).

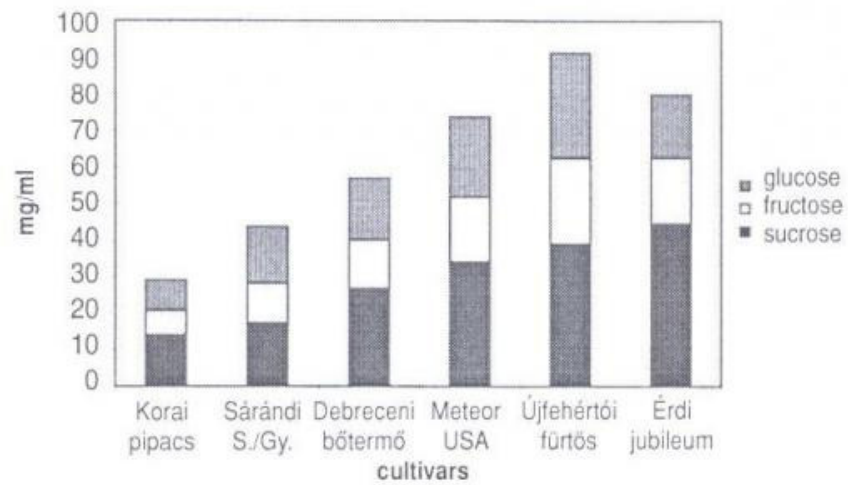

Figure 1 Sugar components of morning nectar sample in sour cherry cultivars, Ujjechértó, 1997

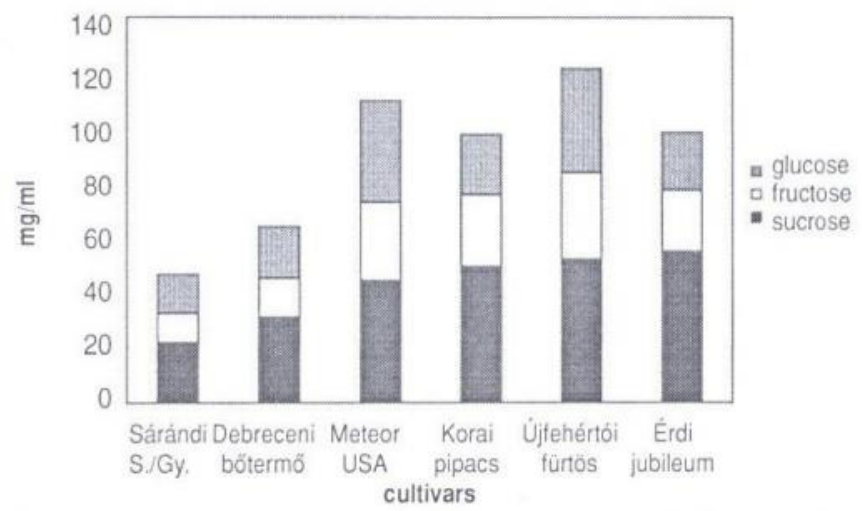

Figure 2 Sugar components of evening nectar sample in sour cherry cultivars, Újfchértó, 1997

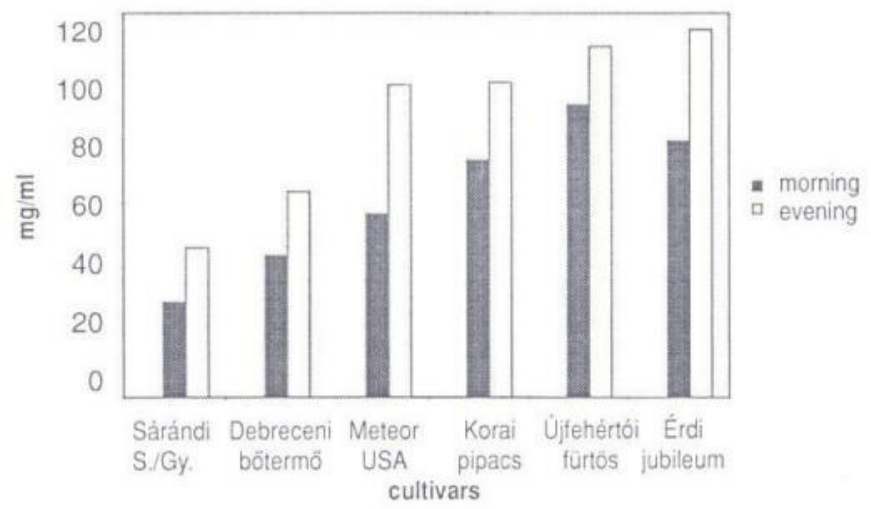

Figure 3 Sugar concentration of morning and evening nectar samples in sour cherry cultivars Újfehértí, 1997

The concentration of nectar varies from opening of the flowers to petal fall to a smaller ('Debreceni bötermö') or greater extent ('Érdi jubileum'). In cv. 'Érdi jubileum' the concentration of nectar sugars in old flowers may be twice as high as that of young flowers (Fig. 5). Nectar composition of flowers in cv. 'Debreceni bötermö' (Fig. 4) is uniformly

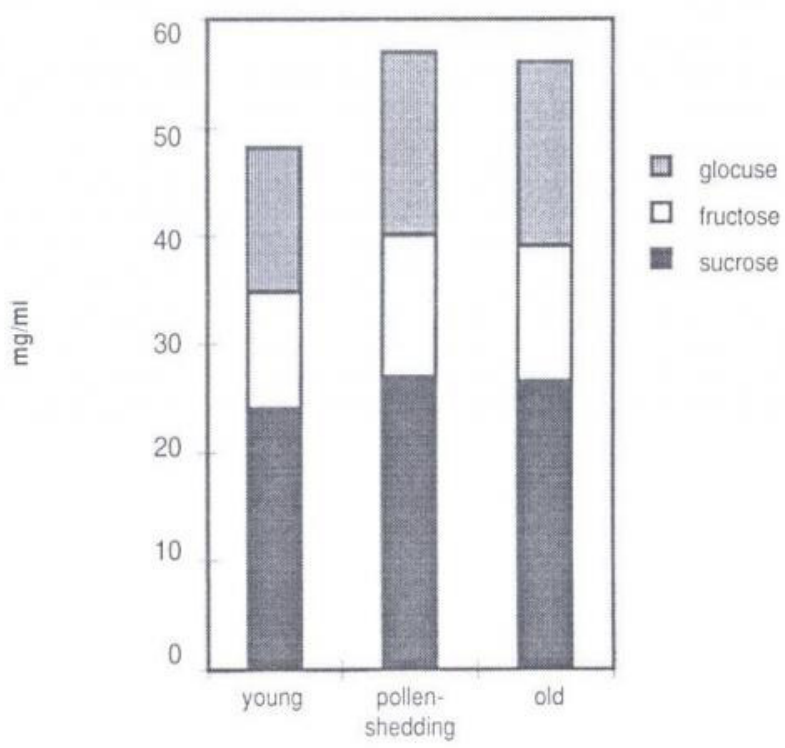

Figure 4 Sugar components of nectar in flowers of different age in sour cherry 'Debreceni bötermö', Ujfehérto, 1997

diluted in the course of bloom, not even reaching the threshold of bee visitation. The flowers of this cultivar were hardly visited by bees.

Cultivar 'Sárándi S/Gy' also has a diluted nectar, which does not differ significantly at night and during 24 hours (Fig. 6-7). The secretory product was not attractive enough for bees either in the morning hours or on the basis of the whole-day nectar production.

On the basis of the average values of total nectar composition, from the 9 studied sour cherry cultivars 'Ujfehértói fürtös' and 'Pándy 48 ' had the most attractive nectar for insects, whereas the least attractive sugar concentration could be found in the nectar of cvs. 'Korai pipacs', 'Sárándi S/Gy', 'Nefris', 'Debreceni bötermö' and 'Montmorency' (Fig. 8).

A linear correlation cannot be searched for between the composition of nectar and fertilisation of flowers, since a great tendency for self-fertilisation may result in good fruitset even in the absence of insect attraction. In one of our previous papers (Orosz-Kovacs et al., 1999) the free fertilisation data of the studied cultivars have been published. On the basis of these it could be stated that the best fruit set $(43.97 \%)$ took place at cv. 'Nefris', whose nectar is not attractive for pollinating bees at all. A good fruit-set $(27.4 \%)$ could be observed, however, at the flowers of cv. 'Ujfehértói fürtös', which had the most advantageous nectar composition among the studied cultivars. The free fertilisation of the autosterile sour cherry cv. 'Pandy 48', whose nectar composition and concentration was the second best, was less satisfactory. In this case free fertilisation was worse because of autosterility. Cultivar 'Debreceni bötermö', whose flowers set fruit in $23.3 \%$, gave a satisfactory yield despite of its diluted nectar, because of its good self-fertilisation ability. Cultivar 'Montmorency' has similar nectar, but because of its possibly protogynous or delayed homogamous flowers it did not give a good fruit-set. 


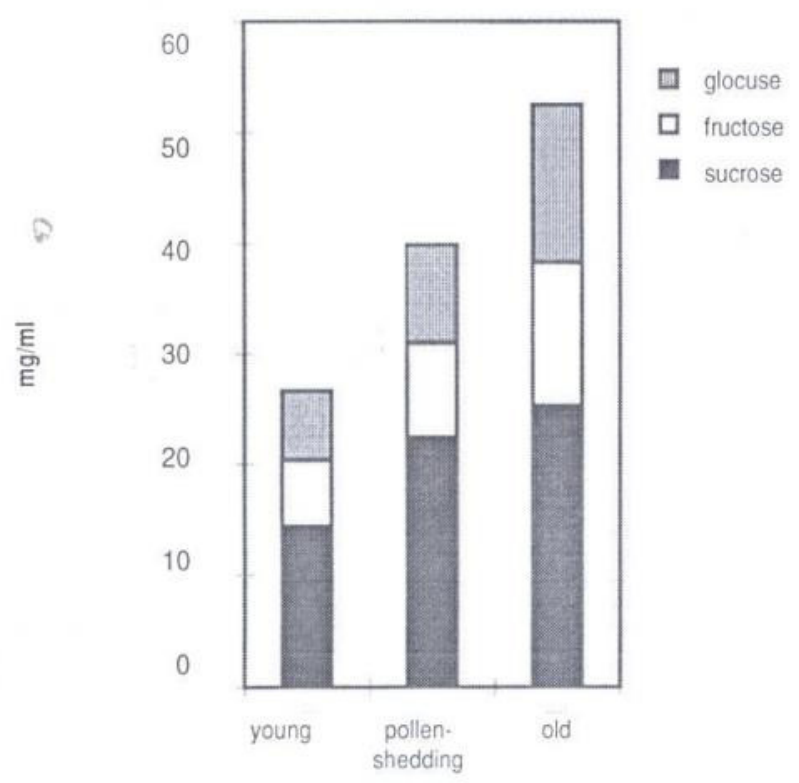

Figure 5 Sugar components of nectar in flowers of different age in sour cherry 'Érdi jubilcum', Újfehértio, 1997

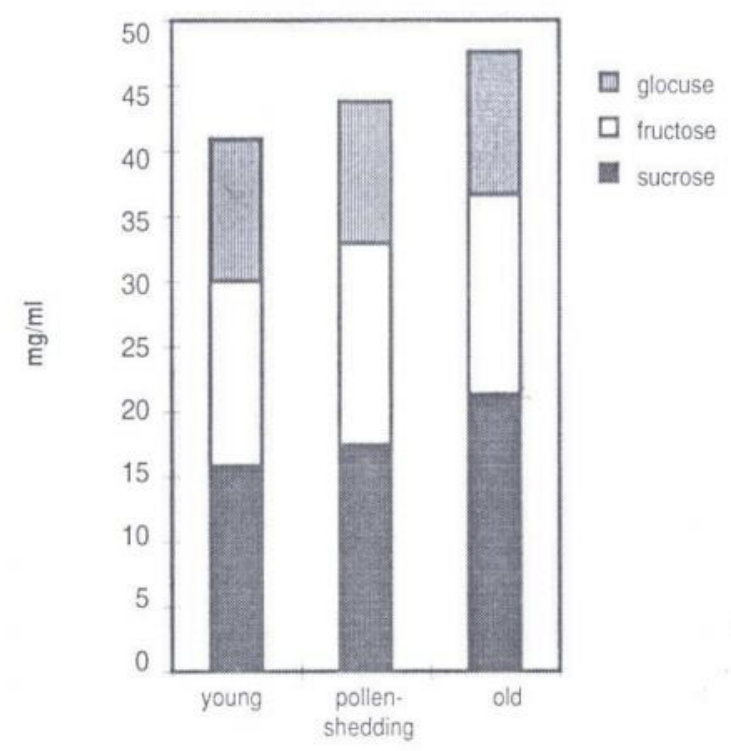

Figure 6 Sugar components of nectar in flowers of different age in sour cherry 'Sárándi S/Gy', Újfehértó, 1997, morning samples

On the basis of their nectar composition the majority of the studied sour cherry cultivars can be classified into the sucrose-rich group, according to the nectar types described by Baker \& Baker (1990). Only one cultivar, 'Érdi jubileum' has a sucrose-dominant secretory product $(\mathrm{S} / \mathrm{G}+\mathrm{F}=1)$. Among cultivars having a sucrose-rich nectar the lowest values were measured at 'Nefris' $(0.59)$ and 'Pándy 48 ' $(0.65)$, i.e. an auto-fertile and an auto-sterile cultivar, respectively, which means that the evaluating system is not suitable for clarifying fertility issues. The nectar of other cultivars in an ascending order of the quotient: 0.75 : 'Ủjfehértói fürtös', 0.76: 'Sárándi S/Gy', 0.79: 'Meteor USA', 0.83: 'Montmorency', 0.93: 'Korai pipacs', 0.95:

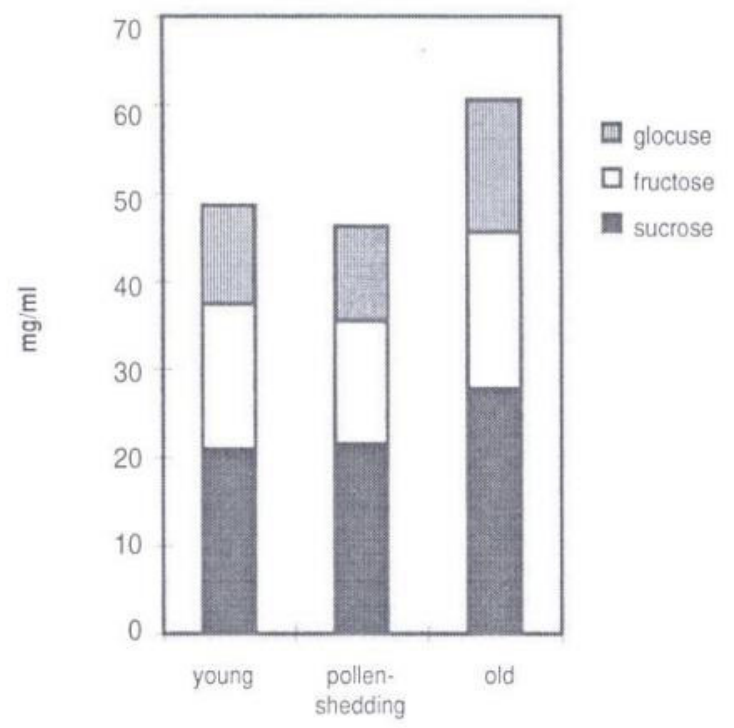

Figure 7 Sugar components of nectar in flowers of different age in sour cherry 'Sárändi S/Gy', Újfchértó, 1997, evening samples

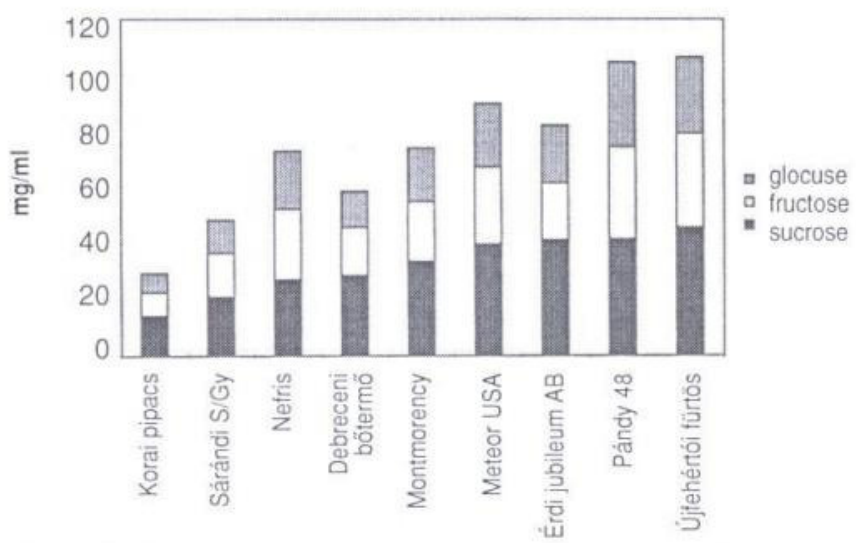

Figure 8 Mean sugar components of nectar in flowers of sour cherry cultivars

'Debreceni bötermő'. The two values nearest to 1 belong to nectars with the lowest concentration. Hence the nectar composition of the studied sour cherry cultivars is preferred by bees and butterflies (Baker \& Baker, 1990). Flower visitation by bees, however, is also influenced by the fact, whether the concentration of the secretory product reaches the threshold value of bee visitation. This value is certainly reached by the nectar of most cultivars in the noon hours, if weather is not too humid and rainy and it is hot enough.

\section{References}

Baker, H. G. \& Baker, I. (1983): Floral nectar sugar constituens in relation to pollinator type (In:Jones, C. E. and R. J. Little (eds): Handbook of Experimental Pollination Biology Van NostrandReinhold). New York. 117-141.

Baker, H. G. \& Baker, I. (1990): The predictive value of nectar chemistry to the recognition of pollinator types. - Izrael Journal of Botany, Vol. 39, 157-166. 
Benedek P. \& Nyéki J. (1997): Considerations on the nectar production and the honeybee visitation of fruit tree flowers. Horticultural Science 29. (3-4): 117-122.

Botz L., Orosz-Kovács Zs., Erdös Z., Timon B., Majerné Bordács M. \& Farkas Á. (2000): Prunoideac gyümölesfajták nektárösszetétele. (Nectar composition of fruit cultivars in Prunoideae) Bot. Közlem. (in press).

Campbell, R. J., Fell, R. D. \& Marini, R. T. (1990): Characterization of Apple Nectar Sugars in Selected Commercial and Crab Apple Cultivars. Fruit Var. J. 44. (3), 136-141.

Davary-Nejad G. H., Szabó Z., Nyéki J. \& Benedek P. (1993): Almafajták virágtulajdonságai és méhmegporzása. (Flower characteristics and bee pollination of apple cultivars.) Kertgazdaság 25(2): 73-88.

Kartashova, N. N. (1965): Stroenie i functia nectarnikov cvetka dvudolnüh rasztenij. Izdatelstvo Tomskogo Universiteta, Tomsk.

Majer-Bordács M., Orosz-Kovács Zs., Gulyás S. \& Erdős Z. (1989): Taxonomic aspects of nectar production in plum cultivars. - Methods and results of biodiversity studies. Budapest, Poster Abstracts 14. (In Hungarian)

Majer-Bordács M., Botz L., Orosz-Kovács Zs. \& Kerek M. M. (1993): The composition of nectar in apricot cultivars - Acta Horticulturae - Tenth International Symposium on Apricot Culture, Izmir, Turkey, 367-371.

Maurizio, A. (1960): Biene und Bienenzucht.-Kapitel Bienenbotanik. München.
Orosz-Kovács Zs. (1991): A cseresznye és a meggy nektáriumstruktúrája és nektárprodukciója. (Nectary structure and nectar production of sweet and sour cherry.) Thesis of Ph. D. Pées. 87.

Orosz-Kovács Zs., Farkas Á., Katona G., Nagy-Tóth E., Bubán T. \& Szabó T. (1999): Floral biological properties deciding in productivity of sour cherry cultivars - Symposium on Fruit Breeding and Genetics - Dresden - Eucarpia Fruit Breeding Section. Horticulture (In press)

Orosz-Kovács Zs., Szabó L. GY., Szabó T., Botz L., Bubán T., Majer-Bordács M. \& Nagy-Tóth E. (1997): Sugar components and refraction of the floral nectar in apple cultivars. Horticultural Science - Kertészeti Tudomány 29. (3-4): 123-128.

Örösi P. Z. (1968): Méhek között (Among bees). Mezögazdasági Kiadó, Budapest 635. (In Hungarian)

Percival, M. S. (1961): Types of nectar in Angiosperms - New Phytol. 60: 235-281.

Simidchiev, T. (1971): Prinosz kam proucsvane nektaroproduktivnosztta i medoproduktivnosztta na visnijata (Cerasus vulgaris Mill.) - Naucsni Trudove na Viszs Syelkosztopanszki Institut V. Kolarov Plovdiv, Plovdiv, XX.5. 87-98.

Szabó L. Gy., Botz L., Orosz-Kovács Zs., Farkas Á., Bubán T., Nagy Tóth E., Szabó T. \& Majerné Bordács M. (2000): Maloideae gyümölesfajták nektárösszetétele. (Nectar composition of fruit cultivars in Maloideae) Bot. Közlem. (in press). 